\title{
Documentary and Guarantee Function of Polish Administrative Court's Dissenting Opinions in Direct Tax Cases
}

\author{
Patryk Kowalski
}

Assistant Professor in The Department of Financial Law, Faculty of Law, University of Lodz, Poland; Judicial trainee in The National School of Judiciary and Public Prosecution in Cracow, Poland

\begin{tabular}{l} 
ARTICLE INFO \\
\hline Keywords: \\
Empirical legal studies \\
Corporate tax \\
Personal income tax \\
Documentary and \\
guarantee function
\end{tabular}

\section{Introduction}

Among the issues related to the deliberation on the ruling and voting of judges in administrative court proceedings, the institution of dissenting opinion (latin: votum separatum, contravotum, abbreviated as "cvs") authorizing the judge of the remaining minority to disclose this fact in an appropriate form is of significant importance, despite the fact that the vote was secret. This regulation, although also appearing in civil and criminal procedure, has not been published in many Polish scientific studies. The most important of them include the following: Bartoszewski 1973; Zdziennicki 2006; Bojańczyk, 2012; Bielska-Brodziak and Tobor, 2013. The belief that a dissenting opinion is not cognitively interesting is still dominant, because its submission is not of great importance for the decision, and is also only the individual interest of the "voted" judge. In addition, in the Polish tax law doctrine, quite the opposite of that in foreign law (Fisher, 2015; Adler, 2000; Epstein, Landes and Posner, 2010), there are no studies analyzing the functioning of the described institution in practice and its importance in the process of applying this branch of law.

The subject of the research conducted in this work is the analysis of dissenting opinions submitted by judges from the judgments of Polish voivodship administrative courts (further: "VAC") in cases of direct taxes in the years 2004-2018.

\footnotetext{
* Corresponding author E-mail address: patryk.kowalski@ wpia.uni.lodz.pl 
A dissenting opinion is a statement, an act of will expressed in the form specified by statute on the part of one of the members of the adjudication panel, different from the majority opinion of its other members. Submission of a contravotum is a procedural act and, for its effectiveness, can be submitted only within the time and form prescribed by the regulations (Bartoszewski, 1973).

The institution of the votum separatum in administrative court proceedings is regulated by an article $137 \S 2$ in fine of the Act of 30 August 2002 Law on Proceedings Before Administrative Courts according to which a judge who does not agree with the majority vote may submit a dissenting opinion when signing the judgement and is obliged to substantiate it in writing before signing the justification. Dissenting opinions may also apply to the justification of the judgment itself. The submission of a dissenting opinion shall be made known, while its author's name can be revealed only upon her/his consent.

The most important from the point of view of the subject and purpose of the development function of dissenting opinions - the documentary and guarantee function - should be emphasized. The documentary aspect of the votum separatum is characterized by the fact that its submission is intended to consolidate the fact of non-unanimous voting and the reasons that determined it. In turn, the guarantee aspect of dissenting opinions states that their submission gives the parties the opportunity to familiarize themselves with the opposite argumentation, which led the judge to vote differently on the decision or justification. In addition, the dissenting opinion constitutes an important reference point for the court of second instance, which may, when considering a remedy, resist or negate the arguments contained in cvs (Bojańczyk, 2012).

Polish taxes can be divided into two groups: direct and indirect taxes. Direct taxes are assessed on personal revenue or property. Indirect taxes are included in the price of goods and services (f. e. value added tax or excise tax). The Polish tax system distinguishes 10 types of direct taxes, including: personal income tax, corporate income tax, inheritance tax, financial transaction tax, real estate tax, agricultural tax, forest tax, vehicle tax, tonnage tax, mineral extraction tax.

One major research (cognitive) objective was set in the study. It is the definition and characterization of the functioning of the institution of votum separatum from the judgements of all Polish VACs in practice. An examination of the above will also allow an assessment of the application of tax law by administrative courts in direct taxes.

Achieving this goal can only occur by solving the main research problem, which was posed in the form of a study question: the application of tax law with respect to which taxes raises the most doubts in the case law of voivodship administrative courts in Poland?

The main research problem posed in this way was used to formulate the research hypothesis, which reads: the application of tax law with respect to personal income tax raises the most doubts in the case law of voivodship administrative courts in Poland, and on the other hand the application of tax law with respect to financial transaction tax raises the least doubt.

\section{Research Methods, Techniques and Tools}

The empirical method of law was used to gather the material necessary to resolve the research problem outlined above. It is a method that confronts the content of applicable law (law in books) with the practice of its application (law in action).

The basic research technique consists in the quantitative and qualitative analysis of the content contained in the collected research material.

To implement this technique, research tools were used such as the Central Database of Judgments of Administrative Courts (http://orzeczenia.nsa.gov.pl) and court rulings contained in it. This database was launched on 1 October 2007 in order to create for interested parties the conditions for the fullest access to the content of administrative court decisions. It contains all 
administrative court rulings issued after the day of its launch by 14 November 2018, and most of the rulings that were issued until 1 January 2004 until 30 September 2007. (Information of the Chairman of the Judicial Information Department of the Supreme Administrative Court of 16 December 2019, reference number WIS.050.676.2019, own collection).

\subsection{Characteristic of The Research Sample}

The research included a sample of judgments of all 16 Polish voivodship administrative courts (Białystok, Bydgoszcz, Gdańsk, Gliwice, Gorzów Wielkopolski, Kielce, Kraków, Lublin, Łódź, Olsztyn, Opole, Poznań, Rzeszów, Szczecin, Warszawa and Wrocław), issued in cases of excise tax, published in the Central Database of Judgments of Administrative Courts (further: "CDJAC"), to which a separate opinion was submitted, issued in the period from 1 January 2004 to 31 December 2018. The sample included rulings browsed against index terms used in the search form, such as "judgement"; "final judgement"; "with a dissenting opinion"; and the thematic slogan - "personal income tax", "corporate income tax", "inheritance tax", "financial transaction tax", "real estate tax", "agricultural tax", "forest tax", "vehicle excise tax", "tonnage tax", "mineral extraction tax".

\section{Research Results}

\subsection{Personal Income Tax}

The analysis of dissenting opinions submitted from VAC's judgments in personal income tax cases shows that judges submit votum separatum very rarely. In the years 2004-2018, voivodship administrative courts issued a total of 24,496 judgments in cases of personal income tax. Only to 33 of them a dissenting opinion was submitted, which constitutes $0.14 \%$ of the total. During the 15-year study period, dissenting opinions were submitted on average 2.2 times a year.

Dissenting opinions from 2 judgments in personal income tax cases were made for the first time in 2004 out of 658 judgments issued by all VAC in Poland, which constituted only $0.30 \%$ of all judgments in personal income tax issued this year. It should also be emphasized that dissenting opinions were submitted fairly regularly. Only in 2008, 2009 and 2013 no judge submitted a dissenting opinion.

The largest number of dissenting opinions, 7, were submitted in 2012, however, it was still a small percentage of judgments issued in personal income tax cases, amounting to less than $1 \%$. It should be emphasized that the noticeably highest percentage of dissenting opinions in personal income tax cases was recorded in 2006 (0.58\%). 698 judgements were issued then and up to 4 of them were dissented. In turn, the lowest percentage of dissenting opinions (except for 0\%) in personal income tax cases was recorded in 2016 (0.05\%). 2050 judgements were issued then, only 1 of them was dissented. Table 1 presents detailed data in this respect.

Table 1.

Judgments issued in personal income tax cases by voivodship administrative courts in the years 2004-2018 together with separate opinions submitted from them - by years

\begin{tabular}{cccc}
\hline $\begin{array}{c}\text { Year of } \\
\text { judgment }\end{array}$ & $\begin{array}{c}\text { Number of judgments of } \\
\text { voivodship administrative courts } \\
\text { in cases of personal income tax }\end{array}$ & $\begin{array}{c}\text { Number of dissenting opinions in } \\
\text { judgments of voivodship administrative } \\
\text { courts in cases of personal income tax }\end{array}$ & $\begin{array}{c}\text { Percentage of dissenting } \\
\text { opinions on personal } \\
\text { income tax }\end{array}$ \\
\hline 2004 & 658 & 2 & $0,30 \%$ \\
2005 & 710 & 3 & $0,42 \%$ \\
2006 & 698 & 4 & $0,58 \%$ \\
2007 & 826 & 2 & $0,25 \%$ \\
2008 & 1745 & 0 & 0 \\
2009 & 1754 & 0 & 0 \\
2010 & 1806 & 2 & $0,11 \%$ \\
\hline
\end{tabular}




\begin{tabular}{lccc}
\hline 2011 & 1882 & 3 & $0,16 \%$ \\
2012 & 1750 & 7 & $0,40 \%$ \\
2013 & 2630 & 0 & 0 \\
2014 & 2253 & 2 & $0,09 \%$ \\
2015 & 2116 & 3 & $0,15 \%$ \\
2016 & 2050 & 1 & $0,05 \%$ \\
2017 & 2174 & 3 & $0,13 \%$ \\
2018 & 1444 & 1 & $0,07 \%$ \\
Sum & $\mathbf{2 4 4 9 6}$ & $\mathbf{3 3}$ & $\mathbf{0 , 1 4 \%}$ \\
\hline
\end{tabular}

Source: own study based on the CDJAC (access: 10.02.2020).

During the 15-year examined period, dissenting opinions were submitted on average 2.1 times for each VAC.

Most often, dissenting opinions from personal income tax judgments were made by judges of the VAC in Wrocław (10 times), and the least often by judges of the VAC in Bydgoszcz, Kraków, Lublin, Olsztyn and Szczecin (1 time). On the other hand, judges in VAC in Kielce, Łódź, Opole, Poznań, Rzeszów and Warszawa never submitted dissenting opinions in personal income tax matters.

It is worth emphasizing that the noticeably highest percentage of dissenting opinions in personal income tax cases was recorded in the VAC in Wrocław (3.72\%). 2681 judgements were issued then, only 10 of them were dissented. In turn, the lowest percentage of dissenting opinions in the abovementioned cases was reported in the VAC in Kraków, Lublin and Szczecin $(0.08 \%)$. There were about 1200 judgements issued there, and dissenting opinion was submitted to only 1 of them. Table 2 presents detailed data in this respect.

Table 2.

Judgments issued in cases of personal income tax by voivodship administrative courts in the years 2004-2018 together with separate opinions submitted from them - according to the jurisdiction of the court

\begin{tabular}{cccc}
\hline Voivodship Administrative & $\begin{array}{c}\text { Number of judgments in } \\
\text { personal income tax cases } \\
(2004-2018)\end{array}$ & $\begin{array}{c}\text { Number of dissenting } \\
\text { opinions in personal income } \\
\text { tax rulings (2004-2018) }\end{array}$ & $\begin{array}{c}\text { Percentage of dissenting } \\
\text { opinions on personal income } \\
\text { tax (2004-2018) }\end{array}$ \\
\hline Białystok & 804 & 5 & $0,62 \%$ \\
Bydgoszcz & 1187 & 1 & $0,09 \%$ \\
Gdańsk & 2387 & 3 & $0,13 \%$ \\
Gliwice & 1948 & 8 & $0,41 \%$ \\
Gorzów Wielkopolski & 1072 & 2 & $0,18 \%$ \\
Kielce & 541 & 0 & 0 \\
Kraków & 1280 & 1 & $0,08 \%$ \\
Lublin & 1260 & 1 & $0,08 \%$ \\
Łódź & 2015 & 0 & 0 \\
Olsztyn & 680 & 1 & $0,15 \%$ \\
Opole & 489 & 0 & 0 \\
Poznań & 1997 & 0 & 0 \\
Rzeszów & 782 & 0 & 0 \\
Szczecin & 1278 & 1 & $0,08 \%$ \\
Warszawa & 4095 & 0 & 0 \\
Wrocław & 2681 & 10 & $3,72 \%$ \\
Sum & $\mathbf{2 4 4 9 6}$ & $\mathbf{3 3}$ & $\mathbf{0 , 1 4 \%}$ \\
\hline
\end{tabular}

Source: own study based on the CDJAC (access: 10.02.2020). 


\subsection{Corporate Income Tax}

The analysis of dissenting opinions submitted from VAC's judgments in corporate income tax cases shows that judges submit votum separatum extremely rarely. In the years 2004-2018, voivodship administrative courts issued a total of 7,546 judgments in cases of corporate income tax. Only to 5 of them a dissenting opinion was submitted, which constitutes $0.07 \%$ of the total. During the 15-year study period, dissenting opinions were submitted on average 0.3 times a year.

Dissenting opinions from 4 judgments in corporate income tax cases were made for the first time in 2005 out of 237 judgments issued by all VAC in Poland, which constituted only 1.69\% of all judgments in corporate income tax issued this year. It should also be emphasized that dissenting opinions were submitted only in 2005 and 2013.

The largest number of dissenting opinions, 4 , were submitted in 2005 , however, it was still a small percentage of judgments issued in personal income tax cases, amounting to less than $2 \%$. 2005 was the year in which the noticeably highest percentage of dissenting opinions in corporate income tax cases was submitted (1.69\%). 237 judgements were issued then and up to 4 of them were dissented. In turn, the lowest percentage of dissenting opinions (except for $0 \%$ ) in corporate income tax cases was recorded in $2013(0.15 \%) .681$ judgements were issued then, only 1 of them was dissented.

Table 3 presents detailed data in this respect.

Table 3.

Judgments issued in corporate tax cases by voivodship administrative courts in the years 20042018 together with separate opinions submitted from them - by years

\begin{tabular}{cccc}
\hline $\begin{array}{c}\text { Year of } \\
\text { judgment }\end{array}$ & $\begin{array}{c}\text { Number of judgments of } \\
\text { voivodship administrative } \\
\text { courts in cases of corporate tax }\end{array}$ & $\begin{array}{c}\text { Number of dissenting opinions in } \\
\text { judgments of voivodship administrative } \\
\text { courts in cases of corporate tax }\end{array}$ & $\begin{array}{c}\text { Percentage of dissenting } \\
\text { opinions on corporate tax }\end{array}$ \\
\hline 2004 & 358 & 0 & 0 \\
2005 & 237 & 4 & $1,69 \%$ \\
2006 & 272 & 0 & 0 \\
2007 & 246 & 0 & 0 \\
2008 & 459 & 0 & 0 \\
2009 & 471 & 0 & 0 \\
2010 & 557 & 0 & 0 \\
2011 & 571 & 0 & 0 \\
2012 & 516 & 0 & 0 \\
2013 & 681 & 1 & $0,15 \%$ \\
2014 & 746 & 0 & 0 \\
2015 & 764 & 0 & 0 \\
2016 & 629 & 0 & 0 \\
2017 & 547 & 0 & 0 \\
2018 & 492 & 0 & 0 \\
Sum & $\mathbf{7 5 4 6}$ & $\mathbf{5}$ & $\mathbf{0 , 0 7 \%}$ \\
\hline
\end{tabular}

Source: own study based on the CDJAC (access: 10.02.2020).

During the 15-year examined period, dissenting opinions were submitted on average 2.1 times for each VAC.

Most often, dissenting opinions from corporate income tax judgments were made by judges of the VAC in Gliwice (4 times), and the least often by judges of the VAC in Gorzów Wielkopolski (1 time). Judges from other courts never submitted dissenting opinions in this matter.

It is worth emphasizing that the noticeably highest percentage of dissenting opinions in corporate income tax cases was recorded in the VAC in Gliwice (0.68\%). 591 judgements were 
issued then, only 1 of them was dissented. In turn, the lowest percentage of dissenting opinions in the abovementioned cases was reported in the VAC in Gorzów Wielkopolski (0.59\%). There were 171 judgements issued there, and dissenting opinion was submitted to only 1 of them. Table 4 presents detailed data in this respect.

Table 4.

Judgments issued in corporate tax cases by voivodship administrative courts in the years 20042018 together with separate opinions submitted from them - according to the jurisdiction of the court

\begin{tabular}{cccc}
\hline $\begin{array}{c}\text { Voivodship Administrative } \\
\text { Court }\end{array}$ & $\begin{array}{c}\text { Number of judgments } \\
\text { in corporate tax cases } \\
(2004-2018)\end{array}$ & $\begin{array}{c}\text { Number of dissenting } \\
\text { opinions in personal corporate } \\
\text { tax rulings (2004-2018) }\end{array}$ & $\begin{array}{c}\text { Percentage of dissenting } \\
\text { opinions on corporate tax } \\
(2004-2018)\end{array}$ \\
\hline Białystok & 223 & 0 & 0 \\
Bydgoszcz & 283 & 0 & 0 \\
Gdańsk & 496 & 0 & 0 \\
Gliwice & 591 & 4 & $0,68 \%$ \\
Gorzów Wielkopolski & 171 & 1 & $0,59 \%$ \\
Kielce & 75 & 0 & 0 \\
Kraków & 380 & 0 & 0 \\
Lublin & 234 & 0 & 0 \\
Łódź & 405 & 0 & 0 \\
Olsztyn & 98 & 0 & 0 \\
Opole & 120 & 0 & 0 \\
Poznań & 555 & 0 & 0 \\
Rzeszów & 255 & 0 & 0 \\
Szczecin & 266 & 0 & 0 \\
Warszawa & 2172 & 0 & 0 \\
Wrocław & 1222 & 0 & 0 \\
Sum & $\mathbf{7 5 4 6}$ & $\mathbf{5}$ & $\mathbf{0 , 0 7 \%}$ \\
\hline
\end{tabular}

Source: own study based on the CDJAC (access: 10.02.2020).

\subsection{Inheritance Tax}

The analysis of dissenting opinions submitted from VAC's judgments in inheritance tax cases shows that judges submit votum separatum extremely rarely. In the years 2004-2018, voivodship administrative courts issued a total of 1,664 judgments in cases of inheritance tax. Only to 1 of them a dissenting opinion was submitted, which constitutes $0.06 \%$ of the total. During the 15-year study period, dissenting opinions were submitted on average 0.07 times a year.

Dissenting opinions from 1 judgment in inheritance tax cases were made for the first and only time in 2007 out of 55 judgments issued by all VAC in Poland, which constituted only $1.82 \%$ of all judgments in inheritance income tax issued this year. In the remaining years no judge submitted a dissenting opinion. Table 5 presents detailed data in this respect.

Table 5 .

Judgments issued in inheritance tax cases by voivodship administrative courts in the years 2004-2018 together with separate opinions submitted from them - by years

\begin{tabular}{cccc}
\hline $\begin{array}{c}\text { Year of } \\
\text { judgment }\end{array}$ & $\begin{array}{c}\text { Number of judgments of } \\
\text { voivodship administrative courts } \\
\text { in cases of inheritance tax }\end{array}$ & $\begin{array}{c}\text { Number of dissenting opinions in } \\
\text { judgments of voivodship administrative } \\
\text { courts in cases of inheritance tax }\end{array}$ & $\begin{array}{c}\text { Percentage of dissenting } \\
\text { opinions on inheritance tax }\end{array}$ \\
\hline 2004 & 28 & 0 & 0 \\
2005 & 16 & 0 & 0 \\
2006 & 29 & 0 & 0 \\
\hline
\end{tabular}




\begin{tabular}{lccc}
\hline 2007 & 55 & 1 & $1,82 \%$ \\
2008 & 191 & 0 & 0 \\
2009 & 173 & 0 & 0 \\
2010 & 172 & 0 & 0 \\
2011 & 155 & 0 & 0 \\
2012 & 95 & 0 & 0 \\
2013 & 168 & 0 & 0 \\
2014 & 144 & 0 & 0 \\
2015 & 149 & 0 & 0 \\
2016 & 80 & 0 & 0 \\
2017 & 114 & 0 & 0 \\
2018 & 95 & 0 & 0 \\
Sum & $\mathbf{1 6 6 4}$ & $\mathbf{1}$ & $\mathbf{0 , 0 6 \%}$ \\
\hline
\end{tabular}

Source: own study based on the CDJAC (access: 10.02.2020).

During the 15-year examined period, dissenting opinions were submitted on average 0.6 times for each VAC.

Only court whose judgment was dissented was VAC in Warsaw (0.30\%). Judges from other courts never submitted dissenting opinions in this matter. Table 6 presents detailed data in this respect.

Table 6.

Judgments issued in inheritance tax cases by voivodship administrative courts in the years 2004-2018 together with separate opinions submitted from them-according to the jurisdiction of the court

\begin{tabular}{cccc}
\hline $\begin{array}{c}\text { Voivodship } \\
\text { Administrative Court }\end{array}$ & $\begin{array}{c}\text { Number of judgments in } \\
\text { inheritance tax cases } \\
(2004-2018)\end{array}$ & $\begin{array}{c}\text { Number of dissenting } \\
\text { opinions in inheritance tax } \\
\text { rulings }(2004-2018)\end{array}$ & $\begin{array}{c}\text { Percentage of dissenting } \\
\text { opinions on inheritance tax } \\
(2004-2018)\end{array}$ \\
\hline Białystok & 33 & 0 & 0 \\
Bydgoszcz & 62 & 0 & 0 \\
Gdańsk & 178 & 0 & 0 \\
Gliwice & 156 & 0 & 0 \\
Gorzów & 32 & 0 & 0 \\
Wielkopolski & 40 & 0 & 0 \\
Kielce & 136 & 0 & 0 \\
Kraków & 55 & 0 & 0 \\
Lublin & 125 & 0 & 0 \\
Łódź & 44 & 0 & 0 \\
Olsztyn & 22 & 0 & 0 \\
Opole & 158 & 0 & 0 \\
Poznań & 34 & 0 & 0 \\
Rzeszów & 108 & 0 & 0 \\
Szczecin & 341 & 1 & $0,30 \%$ \\
Warszawa & 140 & 0 & 0 \\
Wrocław & $\mathbf{1 6 6 4}$ & $\mathbf{1}$ & $\mathbf{0 , 0 6 \%}$ \\
Sum & & 0 & \\
\hline
\end{tabular}

Source: own study based on the CDJAC (access: 10.02.2020).

\subsection{Financial Transaction Tax}

The analysis of dissenting opinions submitted from VAC's judgments in financial transaction tax cases shows that judges submit votum separatum rarely. In the years 2004-2018, voivodship administrative courts issued a total of 2,164 judgments in cases of financial transaction tax. Only to 20 of them a dissenting opinion was submitted, which constitutes 
9.24\% of the total. During the 15-year study period, dissenting opinions were submitted on average 1.3 times a year.

Dissenting opinions from 9 judgments in financial transaction tax cases were made for the first time in 2011 out of 473 judgments issued by all VAC in Poland, which constituted only $1.90 \%$ of all judgments in financial transaction tax issued this year. It should also be emphasized that dissenting opinions were submitted only in 2011, 2013-2015.

2015 was the year in which the noticeably highest percentage of dissenting opinions in financial transaction tax cases was submitted (4.07\%). 221 judgements were issued then and up to 9 of them were dissented. In turn, the lowest percentage of dissenting opinions (except for $0 \%$ ) in financial transaction tax cases was recorded in 2013 (0.34\%). 291 judgements were issued then, only 1 of them was dissented. Table 7 presents detailed data in this respect.

Table 7.

Judgments issued in financial transaction tax cases by voivodship administrative courts in the years 2004-2018 together with separate opinions submitted from them - by years

\begin{tabular}{cccc}
\hline $\begin{array}{c}\text { Year of } \\
\text { judgment }\end{array}$ & $\begin{array}{c}\text { Number of judgments of } \\
\text { voivodship administrative courts in } \\
\text { cases of financial transaction tax }\end{array}$ & $\begin{array}{c}\text { Number of dissenting opinions in } \\
\text { judgments of voivodship } \\
\text { administrative courts in cases of } \\
\text { financial transaction tax }\end{array}$ & $\begin{array}{c}\text { Percentage of dissenting } \\
\text { opinions on financial } \\
\text { transaction tax }\end{array}$ \\
\hline 2004 & 125 & 0 & 0 \\
2005 & 17 & 0 & 0 \\
2006 & 15 & 0 & 0 \\
2007 & 38 & 0 & 0 \\
2008 & 51 & 0 & 0 \\
2009 & 77 & 0 & 0 \\
2010 & 125 & 0 & 0 \\
2011 & 473 & 9 & $1,90 \%$ \\
2012 & 270 & 0 & 0 \\
2013 & 291 & 1 & $0,34 \%$ \\
2014 & 168 & 1 & $0,60 \%$ \\
2015 & 221 & 9 & $4,07 \%$ \\
2016 & 120 & 0 & 0 \\
2017 & 102 & 0 & 0 \\
2018 & 71 & 0 & 0 \\
Sum & $\mathbf{2 1 6 4}$ & $\mathbf{2 0}$ & $\mathbf{9 , 2 4 \%}$ \\
\hline
\end{tabular}

Source: own study based on the CDJAC (access: 10.02.2020).

During the 15-year examined period, dissenting opinions were submitted on average 1.25 times for each VAC.

Most often, dissenting opinions from financial transaction tax judgments were made by judges of the VAC in Lódź (18 times), and the least often by judges of the VAC in Gliwice and Bydgoszcz (1 time). Judges from other courts did not submit dissenting opinions at all.

It is worth emphasizing that the noticeably highest percentage of dissenting opinions in financial transaction tax cases was recorded in the VAC in Łódź (11.25\%). 160 judgements were issued then, only 18 of them were dissented. In turn, the lowest percentage of dissenting opinions in the abovementioned cases was reported in the VAC in Gliwice (0.37\%). There were 271 judgements issued there, and dissenting opinion was submitted to only 1 of them. Table 8 presents detailed data in this respect. 
Table 8 .

Judgments issued in financial transaction tax cases by voivodship administrative courts in the years 2004-2018 together with separate opinions submitted from them - according to the jurisdiction of the court

\begin{tabular}{cccc}
\hline $\begin{array}{c}\text { Voivodship } \\
\text { Administrative Court }\end{array}$ & $\begin{array}{c}\text { Number of judgments in } \\
\text { financial transaction tax } \\
\text { cases (2004-2018) }\end{array}$ & $\begin{array}{c}\text { Number of dissenting opinions } \\
\text { in financial transaction tax } \\
\text { rulings (2004-2018) }\end{array}$ & $\begin{array}{c}\text { Percentage of dissenting opinions } \\
\text { on financial transaction tax } \\
(2004-2018)\end{array}$ \\
\hline Białystok & 24 & 0 & 0 \\
Bydgoszcz & 43 & 1 & $2,33 \%$ \\
Gdańsk & 127 & 0 & 0 \\
Gliwice & 271 & 1 & $0,37 \%$ \\
Gorzów & 30 & 0 & 0 \\
Wielkopolski & 40 & 0 & 0 \\
Kielce & 130 & 0 & 0 \\
Kraków & 154 & 0 & 0 \\
Lublin & 160 & 18 & $11,25 \%$ \\
Łódź & 36 & 0 & 0 \\
Olsztyn & 22 & 0 & 0 \\
Opole & 177 & 0 & 0 \\
Poznań & 41 & 0 & 0 \\
Rzeszów & 74 & 0 & 0 \\
Szczecin & 664 & 0 & 0 \\
Warszawa & 171 & 0 & 0 \\
Wrocław & $\mathbf{2 1 6 4}$ & $\mathbf{2 0}$ & $\mathbf{9 , 2 4 \%}$ \\
Sum & Com & \\
\hline
\end{tabular}

Source: own study based on the CDJAC (access: 10.02.2020).

\subsection{Real Estate Tax}

The analysis of dissenting opinions submitted from VAC's judgments in real estate tax cases shows that judges submit votum separatum very rarely. In the years 2004-2018, voivodship administrative courts issued a total of 12,485 judgments in cases of real estate tax. Only to 10 of them a dissenting opinion was submitted, which constitutes $0.80 \%$ of the total. During the 15 -year study period, dissenting opinions were submitted on average 0.7 times a year.

Dissenting opinions from 2 judgments in real estate tax cases were made for the first time in 2006 out of 180 judgments issued by all VAC in Poland, which constituted only $0.11 \%$ of all judgments in real estate tax issued this year. It should also be emphasized that dissenting opinions were submitted only in 2006, 2008, 2009, 2013, 2014 and 2017.

The largest number of dissenting opinions, 2, were submitted in 2006, 2009, 2014 and 2017. It should be emphasized that the noticeably highest percentage of dissenting opinions in personal income tax cases was recorded in $2009(0.41 \%)$. 488 judgements were issued then and up to 2 of them were dissented. In turn, the lowest percentage of dissenting opinions (except for $0 \%$ ) in personal income tax cases was recorded in 2013 (0.10\%). 1006 judgements were issued then, only 1 of them was dissented. Table 9 presents detailed data in this respect.

Table 9.

Judgments issued in real estate tax cases by voivodship administrative courts in the years 2004-2018 together with separate opinions submitted from them - by years

\begin{tabular}{cccc}
\hline $\begin{array}{c}\text { Year of } \\
\text { judgment }\end{array}$ & $\begin{array}{c}\text { Number of judgments of } \\
\text { voivodship administrative courts } \\
\text { in cases of real estate tax }\end{array}$ & $\begin{array}{c}\text { Number of dissenting opinions in } \\
\text { judgments of voivodship administrative } \\
\text { courts in cases of real estate tax }\end{array}$ & $\begin{array}{c}\text { Percentage of dissenting } \\
\text { opinions on real estate tax }\end{array}$ \\
\hline 2004 & 199 & 0 & 0 \\
2005 & 61 & 0 & 0 \\
\hline
\end{tabular}




\begin{tabular}{lccc}
\hline 2006 & 180 & 2 & $0,11 \%$ \\
2007 & 345 & 0 & 0 \\
2008 & 581 & 1 & $0,17 \%$ \\
2009 & 488 & 2 & $0,41 \%$ \\
2010 & 663 & 0 & 0 \\
2011 & 841 & 0 & 0 \\
2012 & 814 & 0 & 0 \\
2013 & 1006 & 1 & $0,10 \%$ \\
2014 & 1271 & 2 & $0,16 \%$ \\
2015 & 1335 & 0 & 0 \\
2016 & 1564 & 0 & 0 \\
2017 & 1759 & 2 & $0,11 \%$ \\
2018 & 1378 & 0 & 0 \\
Sum & $\mathbf{1 2 4 8 5}$ & $\mathbf{1 0}$ & $\mathbf{0 , 8 0 \%}$ \\
\hline
\end{tabular}

Source: own study based on the CDJAC (access: 10.02.2020).

During the 15-year examined period, dissenting opinions were submitted on average 0.6 times for each VAC.

Most often, dissenting opinions from real estate tax judgments were made by judges of the VAC in Bydgoszcz (3 times), and the least often by judges of the VAC in Gorzów Wielkopolski, Poznań and Szczecin (1 time).

It is worth emphasizing that the noticeably highest percentage of dissenting opinions in real estate tax cases was recorded in the VAC in Bydgoszcz (0.53\%). 566 judgements were issued then, only 3 of them were dissented. In turn, the lowest percentage of dissenting opinions in the abovementioned cases was reported in the VAC in Szczecin $(0.08 \%)$. There were 1329 judgements issued there, and dissenting opinion was submitted to only 1 of them.

Table 10 presents detailed data in this respect.

Table 10.

Judgments issued in real estate tax cases by voivodship administrative courts in the years 2004-2018 together with separate opinions submitted from them-according to the jurisdiction of the court

\begin{tabular}{cccc}
\hline $\begin{array}{c}\text { Voivodship Administrative } \\
\text { Court }\end{array}$ & $\begin{array}{c}\text { Number of judgments in real } \\
\text { estate tax cases (2004-2018) }\end{array}$ & $\begin{array}{c}\text { Number of dissenting } \\
\text { opinions in real estate tax } \\
\text { rulings (2004-2018) }\end{array}$ & $\begin{array}{c}\text { Percentage of dissenting } \\
\text { opinions on real estate tax } \\
(2004-2018)\end{array}$ \\
\hline Białystok & 368 & 0 & 0 \\
Bydgoszcz & 566 & 3 & $0,53 \%$ \\
Gdańsk & 881 & 0 & 0 \\
Gliwice & 2121 & 2 & $0,10 \%$ \\
Gorzów Wielkopolski & 553 & 1 & $0,18 \%$ \\
Kielce & 248 & 0 & 0 \\
Kraków & 544 & 0 & 0 \\
Lublin & 667 & 0 & 0 \\
Lódź & 685 & 0 & 0 \\
Olsztyn & 464 & 0 & 0 \\
Opole & 188 & 0 & 0 \\
Poznań & 1961 & 1 & $0,05 \%$ \\
Rzeszów & 407 & 0 & 0 \\
Szczecin & 1329 & 1 & $0,08 \%$ \\
Warszawa & 452 & 0 & 0 \\
Wrocław & 1051 & 2 & $0,19 \%$ \\
Sum & $\mathbf{1 2 4 8 5}$ & $\mathbf{1 0}$ & $\mathbf{0 , 8 0 \%}$ \\
\hline
\end{tabular}

Source: own study based on the CDJAC (access: 10.02.2020). 


\section{Summary of The Results}

The quantitative and qualitative research allowed to make the most important findings:

a. judges of the VAC submit cvs objectively extremely rarely in corporate income tax and inheritance tax. In the years 2004-2018 in corporate income tax cases judges have submitted dissenting opinion in 5 cases out of 7,546, which constitutes $0.07 \%$ of the total. In the years 2004-2018 in inheritance tax cases judges have submitted dissenting opinion in 1 case out of 1,664 , which constitutes $0.06 \%$ of the total;

b. judges of the VAC submit cvs objectively very rarely in personal income tax and real estate tax cases. In the years 2004-2018 in personal income tax cases judges have submitted dissenting opinion in 33 cases out of 24,496 , which constitutes $0.14 \%$ of the total. In the years 2004-2018 in real estate tax cases judges have submitted dissenting opinion in 10 cases out of 12,485 , which constitutes $0.80 \%$ of the total;

c. judges of the VAC submit cvs objectively rarely and subjectively often in financial transaction tax cases. In the years 2004-2018 in financial transaction tax cases judges have submitted dissenting opinion in 20 cases out of 2,164 , which constitutes $9.24 \%$ of the total;

d. generally, the highest number of cvs were submitted by judges in personal income tax cases (33 times) and the lowest number of cvs were submitted by judges in inheritance tax cases (1 time);

e. the rarity of submitting dissenting opinions also applies to the years. The highest number of cvs were submitted by judges in 2011 and 2015 (12 times). The lowest number of cvs were submitted by judges in 2008, 2016 and 2018 ( 1 time);

f. the occasional nature of dissenting opinions also applies to individual voivodship administrative courts. The highest number of cvs were submitted by judges in VACs in Łódź (18 times). The lowest number of cvs were submitted by judges in VACs in Kielce and Rzeszów (0 times);

g. judges of the VAC submit cvs objectively extremely rarely in direct tax cases. In the years 2004-2018 judges have submitted dissenting opinion in 69 cases out of 48,355, which constitutes $0.14 \%$ of the total.

h. judges of the VAC have never submitted cvs in furthermentioned taxes: agricultural tax, forest tax, vehicle tax, tonnage tax, mineral extraction tax.

i. a small number of votum separatum submitted from the rulings of the VAC regarding direct tax cases may indicate the predictability of the judicial process of applying tax law and, consequently, the implementation of the constitutional principle of legal certainty (at least at the stage of first instance);

j. a small number of votum separatum submitted from the rulings of the VAC regarding direct tax cases may also indicate the unambiguity of tax law and, consequently, the implementation of the constitutional principle of correct legislation (at least at the stage of first instance).

The research hypothesis put forward at the beginning of the study, "the application of tax law with respect to personal income tax raises the most doubts in the case law of voivodship administrative courts in Poland, and on the other hand the application of tax law with respect to financial transaction tax raises the least doubts", was not positively validated in its entirety. The conducted research indicates that the application of tax law with respect to financial transaction tax raises the most doubts in the case law of voivodship administrative courts in Poland, and on the other hand the application of tax law with respect to agricultural tax, forest tax, vehicle tax, tonnage tax, mineral extraction tax raises the least doubts. However, in cases regarding personal income tax judges submitted the largest number of dissenting opinions. 


\section{Discussion and Conclusion}

The analysis certainly does not exhaust all issues related to dissenting opinions in the jurisprudence of administrative courts in tax matters and their importance in applying tax law. It would be worth examining dissenting opinions in judgments concerning other taxes, $\mathrm{f}$. e. indirect taxes, also in terms of comparative law. Due to the nature of the study, of which the article is part, these issues could not be addressed here. However, further work is planned in this area.

\section{Acknowledgment}

The article was prepared on the basis of a paper entitled "Polish Voivodship Administrative Court's Dissenting Opinions in Direct Tax Cases (2004-2018). Quantitative and Qualitative Analysis" delivered in Rome 2020 during the $8^{\text {th }}$ International Conference on Modern Approach in Humanities. Author of this article is grateful for the opportunity to participate in abovementioned conference.

\section{References}

Alder, J. (2000). Dissents in courts of last resort: tragic choices?. Oxford Journal of Legal Studies, 20(2), 221-246. https://doi.org/10.1093/ojls/20.2.221

Bartoszewski J. (1973). Zdania odrębne w procesie karnym, Warszawa.

Bielska-Brodziak, A., Tobor, Z. (2013). Zdania odrębne w orzecznictwie podatkowym. Przeglad Podatkowy, 9(1), 9-13.

Bojańczyk, A. (2012). Zdania odrębne w postępowaniu karnym. Forum Prawnicze, 12, pp. 312.

Epstein, L., Landes, W.M., Posner, R.A. (2010). Why (and When) Judges Dissent: A Theoretical and Empirical Analysis, John M. Olin Law \& Economics Working Paper No. 510 (2D Series), Chicago.

Fisher, R. (2015). Judicial dissent in taxation cases: The incidence of dissent and factors contributing to dissent. eJournal of Tax Research, 13, pp. 470-490.

Zdziennicki, B. (2006). Zdania odrębne w orzecznictwie polskiego Trybunału Konstytucyjnego, [in:] Księga XX-lecia orzecznictwa Trybunału Konstytucyjnego, ed. M. Zubik, Warszawa.

The Act of 30 August 2002 Law on Proceedings Before Administrative Courts, consolidated text of Dz. U. 2019, item 2325, as amended.

The Central Database of Judgments of Administrative Courts (2020). Available: http://orzeczenia.nsa.gov.pl.

Information of the Chairman of the Judicial Information Department of the Supreme Administrative Court of 16.12.2019, reference number WIS.050.676.2019, own collection. 